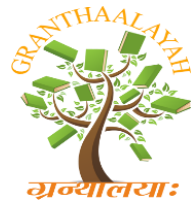

Arts

\author{
INTERNATIONAL JOURNAL OF RESEARCH - \\ GRANTHAALAYAH \\ A knowledge Repository
}

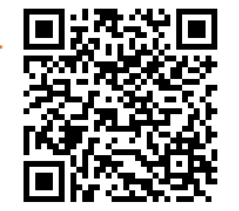

\title{
IMAGE, BRAND AND THE SACRED (INDIA)
}

\author{
Sudhir Kumar *1 \\ ${ }^{* 1}$ Research Scholar, Department of Fine Arts, \\ Aligarh Muslim University, INDIA
}

\begin{abstract}
In the age of global digital revolution the ways of seeing things, the concept of visuality, frequency of images, their interplay and the multiplicity of their meaning have tended to become the culture of the day. Proliferation of screen culture, plethora of print images and the abundance of commercial visuals all around have caused an unprecedented changes in the methods of consuming images within the cultures. In India, where it is difficult to imagine a culture without images and visuals, 'seeing' consists more than what is commonly considered mere as ocular sight. 'Seeing' cannot be without ethics in India and images here always need a positive symbolism, and a sense of sacredness is always attached to the most of them. Branding in an age of visual proliferation has more to depend on the dynamics of images and the visual symbols which situate themselves at the liminal zones between consumers' own real world and the virtual worlds of the brands projected by corporate sectors. This paper taking ethico-spiritual stance attempts at rethinking on the present approaches of branding in Indian context where consideration for dominant and diverse visual cultures appear to be pertinent.
\end{abstract}

Keywords:

advertising and publicity, branding and visuality, branding strategies, consumer culture, corporate ethics, darśan, dynamics of images, screen culture, management and spirituality, visual communication, visual culture in India.

Cite This Article: Sudhir Kumar, "IMAGE, BRAND AND THE SACRED (INDIA)" International Journal of Research - Granthaalayah, Vol. 3, No. 11(2015): 106-121.

\section{INTRODUCTION}

Visual culture of a region or nationality directly affects the methods undertaken or the strategies determined for branding of a consumer product or service for marketing in that area. Considering branding in India's case can be very interesting, as this is the country where the ways of communication heavily depend on the dynamics of images. India is a country where diverse forms of arts, both traditional and contemporary, use a wide range of visual vocabulary seen in the forms of various classical and indigenous traditions embedded throughout her geography. Examining the role of images in Indian culture and the significance of visuality as it is understood in this context, this paper is an attempt to develop a conceptual framework whereby the branding strategies should 
be developed to suit the business activities in India. Conceptually, this paper aims at opening a debate that would evoke questions on the ways the branding strategies are currently determined and the advertisements are being conceived in the country where there is so much emphasis on spirituality and the organic way of life. As India is a country where the ways of life are highly dependent on visual vocabularies, the images and the ways they are consumed can be the important factors in determining the ethics and the strategies behind branding. The paper specially focuses on the visual dimensions of branding and discusses it in relation to the contemporary developments in visual culture, and the Indian ways of seeing.

The course of the flow of this paper starts with a brief discussion on the nature of Indian visual vocabulary, its working, and similarities with brand imagery. Then it proceeds on to discuss the core aspects of branding, its ethical correlation with target culture, and its ineluctable dependence on visuality. For further contextualization of the concept of branding, the insights on contemporary visual culture has been discussed in relation with the specific visual tools used for branding; and then there is an attempt to have an observation on some of the pertinent issues with current modes of branding which are more oriented towards materialism rather than motivating humans for higher pursuits in life as the traditional visual vocabulary of the land does. Thereupon, the discourse moves into a brief note on the Indian perspectives on visuality to provide a glimpse of the characteristic uniqueness of Indian ways of seeing and the sacredness of Indian geography that demands a very special approach and the needful attention for a separate set of considerations for determining the branding strategies in India.

\section{NATURE OF INDIAN VISUAL VOCABULARY AND BRANDING}

Since India's emerging as one of the greatest and the most ancient civilization of the world people here have been successfully trying to express the various moods of their emotions, their understanding of the various phenomena of nature and the mysteries of universe through a vast array of images. In India images play an integral part in any activity done by her people. It is this inclination towards visuality that has tended Indians to explain even the subtlest dimensions of metaphysical and abstract realities like cosmic rhythm, sound, touch, taste, smell, etc. through the use of drawings and colours which are seen in the form of images of various gods and goddesses and their corresponding elemental resonances in yantra drawings in Indian arts and rituals (Rude, 2010). Even the conceptions which seem impossible for visually being depicted such as - the time and cycles of nature - have found this possibility in India through the visual appropriations of swāstika, kālachakra (Mishra, 2000), kāli (Pattanaik, 2006a) etc. Even the music which is said to be having the capacity to touch the innermost cores of our heart has been attempted in India to be represented visually in the rägamala genre of paintings of the medieval period (Fuchser, 2000).

The most profound ideas like creativity, wisdom and love with divine inputs have also found their beautiful expressions in images like saraswati (Pattanaik, 2006b), prajnāpārmita (Ohler, n. a.), and rāsalīla (Schweig, 2005) respectively. The facts which are sometimes dreadful but true such as death and catastrophe have been very simply depicted in terms of iconic representations like yama (Wilkins, 2009a) and vritra (Wilkins, 2009b). The embodiment of compassionate being at its best in the forms of bodhisattvas equally for one and all (Panda, 2011), the most idealized embodiment of renunciation in the form of Budhha, and the embodiment of victory over all human cravings, passions and desires in the form of Jinas or Kevalins (Coomaraswamy, 1994), etc. 
exemplify the power of Indian visual vocabulary which create a complex matrix in which the Indian ways of life are intertwined. Long before when there appeared such devices like cameras and camcorders, there have been remarkable attempts in India to capture in paintings and sculptures even the shortest fleeting moments of the various dance gestures performed in devotion to the divine providence (Nath, 1986). Even the architectural plans in the forms of vāstupurusha (Ananth, 1998), and the planetary positions and conjunctions thereof in the form of navagraha devatās and their influence on human lives (Sivapriyananda, 1990), all have found their visual expressions in India. Now the question is - In what ways all these examples serve the aim of this discussion on branding in Indian context?

Heeding the purposes of this wide arrayed visual vocabulary in India it is found that this unique vocabulary was adopted as the same approach as that of today's concept of branding to reach the masses with divine messages of wisdom. Before it could reach them, this specific but exhaustive amount of multi-layered information was intelligibly modulated according to the different receptive capacities and the psychological dispositions of the people living around the Indian subcontinent. Though the goal behind adopting such visual approach by the ancestors of Indians were different in many ways from that of the present common goals of branding, the methods and workings of both the approaches adopted are in several ways very similar. The goal behind adopting traditional visual vocabulary in India was to transmit the ideas related to better ways of life and culture that were witnessed by the seers in their deepest meditations and life experiences. It was intended to make people evolve both at spiritual and cultural levels. But having an economical motive in branding, the latent ambition behind its working is specifically intended to make as much profit as possible by adding certain status values to a product or a service (Fan, 2005).

It is very interesting to see that in both the approaches - the Indian visual vocabulary and the present concept of branding - there are many noticeable similarities. Both encourage a specific lifestyle and ultimately both have the capability of cultivating a sense of culture among the people. The workings of the both are designed such that they may share people's 'inner lives, their values, their beliefs, their politics' and even their souls (Fan). Both have their influence on the socioeconomical lives of the people. As this Indian visual vocabulary when at play at its matrix level it constructs a code of behaviours that the individuals have to follow at social or economical level. When seen in relation to the welfare of society, culture and the environment this code of behaviors, with the passage of time taken as to be the ethics by the people and homogenously assimilated in their lives as the integral components. Similarly, branding is also a socio-economical construct in which a special form of behavior is expected from both the consumers and the representatives of the company who have adopted a particular brand (Fan). Thus, in respect of its working the concept of branding has to a great extent many similarities with this unique visual vocabulary of India.

\section{ETHICAL NECESSITY IN BRANDING}

Just as the visual vocabulary in India is based on various ideals and interpretations of human values and ethics which are essential for the harmonious survival of the masses with various elements and organisms in nature and environment, the brands also need to proliferate by following certain norms of ethics which must be suitable to the culture and the environment in which it is launched for doing business. Ethics in corporate areas is explained in several ways such as - Business Ethics, 
Corporate Compliance, Corporate Governance, Corporate Responsibility, Corporate Social Responsibility (CSR), Corporate Sustainability, etc. All such ways of explaining ethics in corporate areas if followed duly by the companies they may contribute to the improvement in the value and status of their brands both among the public and corporate sectors (Hurst, 2004).

Ethics in terms of corporate branding is strictly laid down as the 'business standards' and 'code of conducts' in the memorandum of a company and implemented by its authorities and it is expected to be strictly followed by its representatives and the employees both at inner and face level of the company so as to develop a particular kind of culture or to say a "world in which the consumer can enter" (Lowell and Hahn, $n$. a. a). While adopting these ethical principles there are some flexibility kept in consideration according to the nature of the various cultures in different countries and regions of the world. For, the ethical principles adopted for one country or culture may not necessarily bring success in another. Besides following the common global 'fixed reference points' of business ethics and social principals, a company has also to follow a specific set of guidelines laid down in consideration with the socio-cultural context at hand, to successfully propagate its brand in a particular country. These set of guidelines are profoundly outlined keeping in view of the popular set of beliefs and practices flourishing in the particular country or region in which the company is intending to enter with a brand for doing business. Michael Ba Banutu-Gomez (2014a) giving his perspective on culture's importance in international business ethics states that-

- Culture is the make-up of society and therefore should not be changed or persuaded to change by other countries or organizations. It is important to also realize that with every culture, laws and ethical issues will be considered because of the way particular societies practice. Therefore studies conducted must be carefully acknowledged in order to help businesses implement the best strategy for doing business internationally... International companies must be able to manage what the company believes is ethically correct without disrespecting the ethical ways of the foreign country...culture differences should be the main focus when planning for international marketing.

Hence, it is clear that the cultural difference has a great role to play in success of a business and, the business as we are witnessing it today is highly dependent on how a company presents its face before its target consumers in the form of its brand (Fan, 2005). Determining the specific branding strategy for specific culture is equally important for the success of a company or the business (Banutu-Gomez, 2014b).

For a business organization and the success of its brand the adequate understanding of the determinants of these cultural differences are of great significance. Ethically it is expected from the business organizations that they will respect such determinants of the target culture. The definition of culture as commonly delineated is that - It is the "collective programming of the mind which distinguishes the members of one group or category of people from another." In another way it may be defined as "the specific learned norms of a group's attitudes, values, and beliefs (Banutu-Gomez 2014c)". Different cultures use different "non-verbal cues to interpret common verbal messages". These non-verbal cues may be any of the "posture, hand gestures, facial expressions, eye contact, proxemics, and touching" of the people (Gary, 2002). These cues when circulated within a culture through images become part of its visual vocabulary. Visual vocabulary in its totality within a culture with its different forms of art, signs, symbols, fashion, landscape, 
etc. provide a unique identity to its members and the societies; thus, finally it becomes its visual culture.

\section{THE NOTION OF VISUAL CULTURE AND THE IMAGE DYNAMICS}

The notion of visual culture is a recent development. It has developed as the extension of western discourses on defining culture, and consequently itself has assumed a vast theoretical sphere in which the issues discussed are not limited to visuality of just artworks but also the modern visual mediums like photography, cinema, television, advertising, etc. It was in fact a counter reaction against the notion of high art and 'elite culture', and aimed at encompassing on broader spectrum of those ideas which are associated with popular visual expressions (Rampley, 2005a). It is mostly based on the idea that traditional forms of art such as drawing, painting, sculpture, engraving etc. are no longer regarded as the only most important forms of visual expression of cultural identity. With the advancement of new technologies of mass production and re-production now the cultures are thronged with many more new forms of visual expression such as - magazine photographs and prints, on-advertising billboards and hoardings, film and television, digital videos, etc. These are now the crucial visual factors that define new cultural identities.

Discourse on visual culture is still not limited to this foregoing list. Newer forms of art such as the installation art, designed objects and commodities, their packaging, fashion and body conscious appearances and its adornment and their visual images, the visuality of architecture, and even the whole view of a city are now the part of discourses in the field of visual culture. The concept of visual culture further extends to how the interaction of images happens with various other fields where the notion of visual perception has also an important role to play. The other areas which are now the important part of such discourses on visual culture may also include tourism and landscape designs, gardening, sports, theatre, opera, ballet, and even the laser light shows and musical performances on stage (Rampley, 2005b). In the words of Nicholas Mirzoeff (2002) - "The transcultural experience of the visual in everyday life is, then, the territory of visual culture." Explaining the premise of visual culture he further adds-

- ...visual culture is a tactic... a fluid interpretive structure, centred on understanding the response to visual media of both individuals and groups. Its definition comes from the questions it asks and issues it seeks to raise. ...it hopes ... to interact with people's everyday lives (1998a).

Aforementioned technological advances together with digital revolution and the internet have drastically transformed the ways of life in many aspects on this planet. Now the images come and go, and they continuously metamorphose like any amorphous matter. The images have unprecedentedly become so dynamic and frequent on the multivariate surfaces and screens that it has become difficult to judge as which one should be called permanent and which one temporary, which one should be given importance and which one to be considered ignorable. We are, in fact, constantly in interaction with images around us. We are always surrounded with the screens and lenses that are constantly producing and displaying images of us. These images on screen are in turn not only making us constantly aware of our identities at various levels but also create and question our pre-held identities, thus producing dream like situations that has an immense capacity 
to affect our emotions, behaviours and choices. Explaining, this situation of contemporary man surrounded with images, Mirzoeff argues that -

- Modern life takes place on screen. Life in industrialized countries is increasingly lived under constant video surveillance from cameras in buses and shopping malls, on highways and bridges, and next to ATM cash machines. More and more people look back, using devices ranging from traditional cameras to camcorders and Webcams. At the same time, work and leisure are increasingly centered on visual media, from computers to Digital Video Disks. Human experience is now more visual and visualized than ever before... (1998b).

With the coming of Internet and smart-phones, digital-tabs and wide-screen TVs, digital projectors and LED-screens we have become more dependent on our ocular faculty. It will be appropriate to call it "Screen Culture" in which we are constantly engaged with screens whether it is on mobile phones or the laptop computers, televisions, or LED Displays. The existence of things is not limited to their physical mass. They exist on multiple levels, one that is original and real and its extensions in the forms of its multiple image reproductions - both in print and digital formats. The power of these images is such that the people live with them like any natural relation in life. They often create their intent emotional identifications with them. Identifying this power of images David Freedberg (1991) sums up on their present ways of consumption as such-

- People are ... aroused by pictures and sculptures; they break pictures and sculptures; they mutilate them, kiss them, cry before them, and go on journeys to them; they are calmed by them, stirred by them, and incited to revolt. They give thanks by means of them, and are moved to the highest levels of empathy and fear.

The relevance of visual technologies today has grown such that it has affected us in many ways we think or live. They have great influence on how do we dress, eat, stand, walk, play, or understand God. The images constantly affect the manners in which we do politics, interpret ethics, understand history, practice science, get education, desire things, express our fear and love, praise or condemn events, appreciate arts, follow religions, etc. They constantly change our beliefs, resolve doubts, provide pleasure or create anxieties, induce fantasies in us and question our habits. The images create manners in which we are gendered, racialized, or forced to involve in warfares. The images promise us profits and also warn of losses, they help us gain control on situations and they greatly become helpful in using business circumstances to our strategic advantage. So, humanity today is highly dependent on the visual vocabularies. The companies and the business organizations having realized the value of this advantageous opportunity are trying to make best use of modern man's dependency on the images and their visual cultures. Here comes the concept of visuality in branding.

\section{BRAND CULTURE AND ITS VISUAL TOOLS}

Though, every branding campaign uses visual tools for its advantage to a great extent, yet unlike this commonly held conception the concept of branding is not only limited to the function of advertising and managing of the 'product image' that can be separated as a different activity from the larger business strategies. Instead, branding should be seen as the 'strategic point of view' 
which lies in center to the motive of creating 'customer value' and, as the most potent instrument for holding a 'competitive advantage'. It is in fact a 'management perspective' that works on this assumption that customer value is never an 'objective fact' but a perceptual decision that is influenced by consumer's subjective experiences. Heilburn defining the term brand states - "A brand may be viewed not solely as a sign added to products to differentiate them from competing goods, but as a semiotic engine whose function is to constantly produce meaning and values (Lowell and Hahn, $n$. a. b)". Brands are the "complex multi-dimensional constructs with varying degrees of meaning, independence, co-creation and scope. Brands are semiotic marketing systems that generate value for direct and indirect participants, society and the broader environment, through the exchange of co-created meaning" (Conejo and Wooliscroft, $n$. $a$.).

Branding treats products as the 'cultural artifacts' which upon circulation within a society get embedded into the web of 'meanings and connotations' which ultimately conventionalize as stories and become the 'accepted truths'. The visual associations such as - logo or trademark or the characteristic 'design features'- that we make with any brand are in fact its 'material markers' which initially have no meaning, but once a brand is launched these 'material markers' start circulating within the culture and become loaded with the meanings and opinions that are constructed around them in the customers' and their friends' experiences, in discussions and texts in various mass media, in films and advertisements, in entertainment and sport events etc. With the passing of time, this 'accumulation of meanings' forms a complex aura around these 'material markers', which later always keep interacting with the customer. Thus evolves the brand culture. Stories, images and associations are the 'cultural materials' which a brand uses as their source material to propagate their own culture. These 'cultural materials' when projected by a brand they are further consumed by the customers as the symbols of "social distinction to make status claims" and to "forge solidarity and identification" with other customers who are also using the same brand (Holt, n. a. a).

For a brand to become successful it needs marketing communication and advertising so that it may secure a 'salient position' in consumers' 'consideration set'. The advertising builds a brand attitude in the consumer's mind which further establishes the grounds for brands success (Percy, 2003). Using 'artifacts (designs or logos and devices in their pure tangible form)' and 'symbols (artifacts combined with specific or brand related meanings)' the business organizations project their selfimage. They use logo, tagline, or a specific colour to emphasize their brand statement. Brand's artifacts are also used by the customers to express their individuality and the emotional relationship with the brand. To make the brand coherent the companies conjures up the approaches like 'living the brand' or 'being the brand' and advertise it on different visual platforms like television, internet, etc. or at some real event. These statements are further re-emphasized by the tangible artifacts chosen for the brand. These artifacts and statement have an exciting effect on the employees who on adopting them find themselves special and different from others, and they enthusiastically transfer their knowledge of brand to the consumers. While the 'symbols' have their role in crafting brand identity, the 'artifacts' become the vehicles for the 'strategic vision' of the company (Schultz et. al., 2004). 


\section{ISSUES WITH CURRENT MODES OF BRAND PROMOTION}

Though it is still an unsettled area, yet if examined how the present ways of advertising or publicity for promoting a brand is done, whether in India or abroad, one may find that it is a strongly held practice of turning traditional knowledge system of 'average spectator buyer' to the own advantages by the business organizations. The traditional knowledge of 'history, mythology, poetry' etc. of the target masses is used for glamorizing a brand. The current publicity strategies modulate the visual language from the target cultures to mythicize their inadequate references in history for their own advantages. They use such tactical means to regulate the consumers' sense of acquiring the things that are projected as real before them. Such trends are in vogue in which the publicity strategies ensure their success on the consumers' fear that if they don't have thus projected 'real thing' they will be doomed to nothing (Berger, 2008a).

It is a general conception among the common consumers that advertisements are intended to transmit information about the products or services but in reality they are tactfully conceived for reshaping the consumers' opinions about the products or services. For this the advertising strategists devise 'dramatic fictions' and 'imaginative metaphors' in which the products or services are "embedded to provoke the audience to think differently about them (Holt, $n$. a. b)".

It is the common practice in advertising world to laud and add sensuality to the products for making them a selling success. Displaying of products in association with some sexual overtone is considered necessary for presenting them as something unique. The products are projected in such a manner as that on having those by the consumers will make them 'sexually desirable'. Brand advertising addressing in 'future tense' through the media of alluring pictures and videos plays the gimmick of highlighting the presumed functioning of a product for buyer's promised 'personal transformation'. Through the images on hoardings, magazine photographs, newspaper advertisements, television programs, web pages, etc. not only the consumers but the others too remain in constant encounter with such promises of future 'personal transformation'. Yet, this promised future of the buyers remains 'endlessly deferred'. There were no such claims through such a high density of 'visual messages' witnessed by the societies in the past (Berger). Examining these approaches of promoting brand values from an ethical perspective the following issues may be pointed out that the business organizations should rethink before branding themselves as Corporate Socially Responsible (CSR) organizations:-

\subsection{ENVY AND ISOLATION}

The brand statements through publicity and advertisements are designed such that they provoke the customer to envy his/her assumed personality that is to be achieved by personal transformation through their products. Conversely, they also incite the customer to become an object of envy for others too (Berger, 2008b). This envy in long turn develops as false pride into the customers' personalities and as their consequence the customers lack attachment from their friends and relatives and lastly find themselves as the isolated lonely individuals in the society. 


\subsection{CONSTANT DESIRE AND ANXIETY}

Products in branding are projected as the signs of good life, affluence and dignity. They are also projected as the symbols of 'cultural value' which a customer should necessarily have in order for being respectable in the society (Berger, 2008c). Tempted by such a notion of dignity attached to the brand products the customers constantly remain in desire to acquire more and more such projected symbols of 'cultural value' and luxury, and they are never able to come out of this insatiable passion, restlessness and anxiety.

\subsection{MONETARY DISPARITY}

In order to create an aura of brand value around the objects on sell they are priced much higher than their actual cost. This imposes an extra economical burden on the average buyers. Even in order for fulfilling their basic needs they have to pay extra sum of money to the sellers. This situation leads to the fast flow of wealth from the people of low income to the ones with higher income. In the countries where average income is comparatively much lower than the developed countries and where no such corporate giants have emerged to counterbalance this monetary disparity the flow of wealth occurs very fast towards the developed nations. This adds to the obstacles in progress of the underdeveloped countries.

\subsection{LOW SELF-ESTEEM}

The buyers with low income who are unable to acquire the high-priced products of well-known brands due to their incapacity to purchase mostly consider their standards of life as comparatively below than that of those who are able to acquire the high-priced brands, and affected by such a low opinion of their lives, they as individuals may have a low self-esteem. This mental block impedes their holistic development and they constantly remain unsatisfied with their falsely presumed ordinary life.

\subsection{EXCESS CONSUMPTION AND POLLUTING OF RESOURCES}

Branding necessitates the specific packaging which requires extra natural resources like iron for making containers, rubber and plastics for packaging, plants and trees are cut for making packaging papers and for creating advertising materials. These also require extra human resources. Thus, wastages of resources and labour occur in the name of branding. Plastics and rubber after the use for packaging are many a time carelessly thrown out by the consumers which take very long time to be decomposed. Consequently, they affect not only the natural beauty of the environment but also pollute the natural resources like soil, water and air, and become very harmful for the living organisms that survive on these resources and use them as their habitats. Moreover, too much of packaging and lavish advertising also increase the cost of production and ultimately unnecessarily hikes the selling prices of the products.

\subsection{MATERIAL IDENTIFICATION}

Under the constant influence of advertising and branding the customers start taking it for granted that they should have those material things that are advertised and it becomes their life's ambition 
to acquire more and more of such things and ultimately they start creating their identifications in those acquired things. They forget the true purpose of life and the duties towards underprivileged fellow citizens and constantly remain engaged in acquiring wealth for fulfilling their own selfish motives. As a result, this selfishness and tendency to hoard more and more whenever they find themselves unable to purchase certain costly things or services, they even do not think it wrong in acquiring them through the means which may be morally questionable.

\subsection{CONTEXTUAL EXCLUSION}

As it has been already observed that the certain claims and promises that are done by the brand advertisements remain 'endlessly deferred'. Still interestingly the customers find credibility in those brand statements. It is because the truthfulness of these brand statements as experienced by the customers does not lie in the fulfillment of these promises, but how they are relevant to the fantasies of the buyers (Berger, 2008d). Thus the buyers start living in a kind of self-created world which is contextually excluded from that of the real world.

\subsection{SPIRITUAL DEGENERATION}

Due to customers' constant exposure to advertisements which most of the time keep emphasizing on material gains and identifications, carnal beauty, luxuries, properties, alluring investment schemes, sexual desirability, vain dignity, etc., they lose their spiritual quotient. They become the individuals of very narrow outlook who is engaged in caring of their own interests or their families or the relatives only, not caring least of their responsibilities towards the nation or the world. Such narrow outlook makes them conceptually blind even for the living organisms in their immediate surroundings and the nature upon which they have to be constantly dependent. This impedes their holistic growth in life and obstructs their extending harmonious relations with other organisms and the environment. Thus, they forget the real meaning of life, yet they remain in vain pride of being counted among their own presumed class of elites. When such state of affairs persists many more individuals get affected by the same vain meanings of success in life and in the long run these pursuits ironically are accepted as the standards for life. Thus, there happens the spiritual degeneration at societies' levels from where coming back would seem very difficult.

Highlighting these issues is in no way aimed to undermine the practice of branding. In fact, apart from its many advantageous roles like - fulfilling the profit making ambitions of business organizations, building a charming image of their products, their quality and the size of their business, making an easy path for the products which are to be launched in future, enhancing the credibility of the products among the consumers, building customers loyalty, "commanding the market price" of the products, etc. (Yudkin and Stork, 2002; Boundless, 2015; and Circle..., 2015, BrandXpress..., n. a.), there are some remarkable benefits of branding from the consumers' perspective too. These benefits have been broadly enumerated by Tim Ambler (1997) as - by the "competition for patronage" among brands the consumer is benefitted considerably; some of the brands do value for money; consistency of branded products gives satisfaction to the consumers and also develop a level of assurance about the quality of their future products among the customers; consumers can make "individual choices" for a product according to their preferences or the needs, and for selection of their purchase items many a time they don't have to try too hard because brand advertisements, though shady to an extent, may still provide relevant information 
about the products or services; the phenomena of branding "reduces search cost" for the customers; the subsidy and sponsorships by the brands many a time make affordable for the people with average income ranges some of those services or the means of entertainments which otherwise in terms of their monetary values would have been out of reach for them; etc.

Thus, it is impossible to discard the whole practice of branding outrightly; instead, there should be efforts for a sustainable and the culture oriented contextual balance between the opposing viewpoints on the issues and the advantages associated with the practice of branding. If the branding has such a great power of manipulating the decision making capacities of the consumers and cultivating a sense of culture, then branding could also motivate and guide humanity for higher pursuits and instilling such sensibilities that may lead them towards organic living and the spiritual upliftment, which are being recognized as the significant keys to cope with such endangering problems of the world like - the rising pollution, the unchecked population, ecological imbalance, global warming, increasing rates of diseases, stress, poverty, corruption, terror, illiteracy, and so on.

\section{BRANDING IN THE CONTEXT OF INDIAN VISUALITY}

Unlike the foregoing uncomfortable observations in relation to the current modes of advertisement and publicity in the branding world, the widely circulated Indian traditional visual vocabulary has its roots in the highly ethico-philosophical traditions still in continuation, since its origin in ancient past. Speaking in terms of this visual vocabulary the whole geography of India with all its diversity is considered sacred. Therefore, wherever one may travel in India or whatever is seen, the experiences thus acquired are always shared in terms of the relation with divine (Eck, 2012). Visuality in India is considered a sacred gesture. It is therefore, in India any image, sculpture, architecture, or a landscape cannot have their bare tangible existence only. They are always associated with the auras of some sacred myth, story, or meaning. The purpose of this association is to relate them with high virtues of life and spirituality. The images in India always need a positive symbolism which hints at the values which are essential for humanity. But in the present situations the experience from a travel around the country would be a sporadic encounter with plethora of advertising images pitted incongruently against the various geographical landscapes of the country. Many a time, these advertising images vulgarly misfit even with the sacred view of a pilgrim centre. A devotee on a pilgrimage cannot have that pure divine experience which one could do here a couple of decades ago. Spiritual spotted with material cannot at all be spiritual. The advertising hoardings at various places around these sacred landscapes deflower the view of divine.

The act of 'seeing' in India is more than mere ocular viewing of a sight. Here seeing does not mean the 'visual perception' only. It is a sacred act. The visual perception admixed with spiritual interaction becomes 'darśan' in India. Darśan emphasizes spiritual interaction between the seer and the seen and the inter-transfer of virtues which enhances the positivity in both - the thoughts and the atmosphere. Darśan is the 'visual perception of the sacred'. The därsanic sense of the term 'seeing' also implies 'being seen'. The act of 'seeing' in ritualistic sense is a form of worship in India. And 'being seen' means gaining blessing from the one we see at. The persons from India out for sightseeing when inadvertently enter into a sacred geography, no sooner as they do become aware of this fact start acting like the pilgrims. They are not the ordinary sightseers now, but 
elevated to be taken as the 'sacred sightseers' who is now not merely interested in the beauty of the sight but also the sacred aura of that geography. He is now interested in experiencing the powerful aura of the supposed presence of divinity pervading that place (Eck, 2007a). Thus, advancing for visual retreat in Indian culture is interpreted as an ambition for pilgrimage which further enables the seer for envisioning that which is imperceptible through sense perceptions. They need a savouring approach, the experiencing of sublime through high devoutness.

This way of 'seeing', a unique and significant aspect of Indian visual culture, has been totally ignored by the business organizations while they plan advertising or project their branding strategies for marketing in India. Visualizing in Indian context cannot be interpreted only in the sense of commodity promotion. Furthermore, the act of viewing in Indian cultural context also implies the connotations of 'touching' and 'knowing' or 'being touched' and 'being known'; especially from a spiritual view point (Eck, 2007b). In other words, the act of 'seeing' or that of 'being seen' is conceptually a tactile act in Indian cultural context. 'Seeing' also means - touching the aura, and 'being seen' also means - being enshrouded in the aura of the visually perceptible object or an image. If the object or image placed or displayed for promotion of a brand is not ethically acceptable it may be said to be contributing to the contamination of the sanctity of the surrounding atmosphere and taken to be inauspicious. Such images may be even taken as to be having the damaging effects on the passers bye.

Branding agencies to a much larger extent tap the visual faculty of the consumers for making an access into their consideration sets for selling their products. That is why they create alluring posters, hoardings, video advertisements on televisions, banners on web pages, box advertisements in the newspapers and magazines, etc. in which the act of seeing lies in the central place. Though, these visuals many a time are very appealing aesthetically, but it is not necessary that there might have efforts to keep them up to the standards which fit the consumers' spiritual sensibilities also. In Indian cultures the spiritual sensibility is given the highest importance in any activity. And, in terms of visuality, as we have observed earlier, "seeing" in India is not just the aesthetical but also a spiritual activity. Thus, before claiming themselves to be the CSR organizations while promoting their brands in India the business organizations should keep this factor on their priority list of ethical guidelines and should have a deep regard for this aspect of Indian culture. The questions of - where to place, what to place, why to place, how to place, and how much to place as the advertising images for promotion of a brand in India, should be pertinent while chipping in for the branding ethics. The issues in question that have been highlighted earlier in the broader context also cannot be sidelined altogether while setting out for strategies of branding in India.

\section{CONCLUSION}

The images with their dynamics serve to become the interface for the consumers through which they enter into the projected virtual world of a brand. But the world that is virtual cannot satisfy the real urges of the masses. Instead, there is a great probability that in the long run they may even alter the notions and standards of what is called a true way of life. As a result, the vision of mankind could become narrower and pose them into an imminent danger of being selfishly materialistic. Therefore, it must have a touch of reality, should be based on the ethics and have regard for the cultures of the target consumers and the geographical environment in which the business organizations are delving to launch their brand. The culture-specific visual symbols, the unsettled 
myths, the gestures, the seemingly inadequacies in traditional knowledge systems are the means that keep the individuals and their thought process active and the societies alive within the cultural zones as these inadequacies and the unsettled domains provide them a space to interact, discuss, interpret and find resolutions on their own based on the circumstances at hand. They are not the means to be exploited or to create a sense of insecurity or the complex of inferiority in the psyche of the people to make commercial advantages by the brand giants. Instead, the brands can be the enthusiastic collaborators in the celebration of the people's respective cultural ethos' to win their hearts. Thus, they can also contribute to the wellness and happiness of the world.

In the Indian visual cultural context the peculiar way of seeing, especially the sense of sacredness and the tactility attached to the concepts of visualilty and image, demands a very special approach towards branding. The images in India becoming more than the objects of mere sense perception or the media for communication, are many a time regarded as living entity which like any other organism are presumed to be able to interact with and act upon their onlookers. Thus they have a very vital role in communication with the psyche of the masses. That is why the images in India are expected to be charged with an ethico-spiritual aura. While laying down the strategies for branding in India the business organizations or the advertising agencies who claim to be socially responsible organizations should have a deep consideration for these unique aspects of Indian visual culture. Thus, they will not only fulfill their economical ambitions but also be able to contribute towards preserving for humanity one of the most beautiful cultures and the spiritualheritage of the world.

\section{ACKNOWLEDGEMENT}

This paper is the revised and expanded version of the article with a different title that was accepted for presentation in the AICTE sponsored International Seminar on Evolving Management Strategies for India's Economic Growth held on 1-2 May, 2015, organized by Oriental College of Management Bhopal (MP), India. Yet, unfortunately the author could not attend it. However, he is extremely grateful to the review team and the organizers of the seminar, because it was the selected themes by them for the event which inspired the author for conceiving the idea discussed in this paper. The author is also thankful to his friend and colleague Hari Om Singh, a research scholar in the same university, who has been always ready for his valuable suggestions and insights in author's contributions.

\section{REFERENCES}

[1] Ambler, Tim (1997). "Do Brands Benefit Consumers?" International Journal of Advertising; 16(3), 167 - 198. Retrieved (the document in MS-Word format) <http://www.researchgate.net/publication/230232564_Do_Brands_Benefit_Consumers> accessed on Nov. 10, 2014.

[2] Ananth, Sashikala (1998). The Penguin Guide to Vaastu: The Classical Indian Science of Architecture and Design, Penguin Books, New Delhi, 91-100.

[3] Banutu-Gomez, M. B. (2014a). "The Role of Culture, Language, and Ethics in Global Business", Proceedings of Global Multidisciplinary Academic Meeting, GAM 2014, 238. Retrieved <http://www.eujournal.org/index.php/esj/article/viewFile/3280/3062> accessed on Nov. 10, 2014. 
[4] Banutu-Gomez, M. B. (2014b). "The Role of Culture, Language, and Ethics in Global Business", Proceedings of Global Multidisciplinary Academic Meeting, GAM 2014, 231 33. Retrieved <http://www.eujournal.org/index.php/esj/article/viewFile/3280/3062> accessed on Nov. 10, 2014.

[5] Banutu-Gomez, M. B. (2014c). "The Role of Culture, Language, and Ethics in Global Business”, Proceedings of Global Multidisciplinary Academic Meeting, GAM 2014, 231. Retrieved <http://www.eujournal.org/index.php/esj/article/viewFile/3280/3062> accessed on Nov. 10, 2014.

[6] Berger, John (2008a). Ways of Seeing, British Broadcasting Corporation and Penguin Books, 129-46.

[7] Berger, John (2008b). Ways of Seeing, British Broadcasting Corporation and Penguin Books, 134.

[8] Berger, John (2008c). Ways of Seeing, British Broadcasting Corporation and Penguin Books, 135.

[9] Berger, John (2008d). Ways of Seeing, British Broadcasting Corporation and Penguin Books, 146.

[10] Boundless (2015). "The Benefits of a Good Brand”, Boundless Business, Boundless, 14 Oct. Retrieved <https://www.boundless.com/business/textbooks/boundless-businesstextbook/product-and-pricing-strategies-15/product-packaging-and-branding-99/thebenefits-of-a-good-brand-465-7936/> accessed on 12 Nov. 2015.

[11] BrandXpress Blog (n. a.). "5 Benefits of Branding". Retrieved <http://www.brandxpress.net/2005/10/5-benefits-of-branding/> accessed on 12 Nov. 2015.

[12] Circle Creative Communications (2015). "Benefits of a Strong Branding". Retrieved <http://circlecc.com/benefits-of-a-strong-brand/> accessed on 12 Nov. 2015.

[13] Conejo, Francisco and Wooliscroft, Ben (n. a.). "Abstract-Brands Defined as Semiotic Marketing Systems".

Retrieved <http://jmk.sagepub.com/content/early/2014/04/16/0276146714531147.abstract> accessed on Nov. 10, 2014.

[14] Coomaraswamy, A. K. (1994). Jaina Art, Munshiram and Manoharlal Publishers Pvt. Ltd. New Delhi, 2-3.

[15] Eck, Diana L. (2007a). Darsan: Seeing the Divine in India, Motilal Banarsidas Publishers Pvt. Ltd., Delhi, 3-7.

[16] Eck, Diana L. (2007b). Darsan: Seeing the Divine in India, Motilal Banarsidas Publishers Pvt. Ltd., Delhi, 9-10.

[17] Eck, Diana L. (2012). India: A Sacred Geography, Harmony Books, New York, 2-4.

[18] Fan, Ying (2005). Ethical Branding and Corporate Reputation; Corporate Communications: An International Journal, Volume 10(4), 341-50.

[19] Ferraro, Gary P. (2002). The Cultural Dimension of International Business; Massachusetts: Prentice Hall, 8.

[20] Freedberg, David (1991). The Power of Images: Studies in the History and Theory of Response, University of Chicago Press, 1.

[21] Fuchser, Susan (2000). Reflections on Ragamala Painting. 25-27. Retrieved <http://digital.library.unt.edu/ark:/67531/metadc146475/m2/1/high_res_d/2000-

23_Fuchser.pdf>accessed on Nov. 13, 2015. 
[22] Holt, Douglus B. (n. a. a). Brands and Branding, Cultural Study Group, 1-6. Retrieved <http://culturalstrategygroup.com/wp-content/uploads/brands-and-branding-csg.pdf> accessed on Nov. 11, 2015.

[23] Holt, Douglus B. (n. a. b). Brands and Branding, Cultural Study Group, 9. Retrieved <http://culturalstrategygroup.com/wp-content/uploads/brands-and-branding-csg.pdf> accessed on Nov. 11, 2015.

[24] Hurst, Nathan E. (2004). Corporate Ethics, Governance and Social Responsibility: Comparing European Business Practices to those in the United States; Markkula Center for Applied Ethics, Santa Clara University, 6-8. Retrieved <http://www.scu.edu/ethics/publications/submitted/hurst/comparitive_study.pdf> accessed on May 22, 2015.

[25] Lowell, Doug and Hahn, Dennis (n. a. a). "Give Them Something to Believe in: The Value of Brand Culture”. 8. Retrieved <http://www.brandframe.no/files/Fagartikler101140/BrandCulture_whtpap1.pdf> accessed on May 27, 2015.

[26] Lowell, Doug and Hahn, Dennis (n. a. b). "Give Them Something to Believe in: The Value of Brand Culture”. 7. Retrieved <http://www.brandframe.no/files/Fagartikler101140/BrandCulture_whtpap1.pdf> accessed on May 27, 2015.

[27] Mirzoeff, Nicholas (1998a). An Introduction to Visual Culture, Routledge, 4-5.

[28] Mirzoeff, Nicholas (1998b). An Introduction to Visual Culture, Routledge, 1.

[29] Mirzoeff, Nicholas (2002). The Visual Culture Reader, Routledge, 41.

[30] Mishra, T. N. (2000). Buddhist Tantra and Buddhist Art (Emerging Perceptions in Buddhist Studies; no. 12), D. K. Printworld (P), Ltd., New Delhi, 39-40.

[31] Nath, R. (1986). "Inter-Relationship of the Performing and the Plastic Arts", Elements of Indian Art and Architecture, The Historical Research Documentation Programme, Jaipur, 85-94.

[32] Ohler, Keith (n. a.). "Prajnaparamita- The Great Mother", Foundations of Buddhism. Retrieved <http://cubuddhism.pbworks.com/w/page/24856081/Prajnaparamita\%20The\%20Great\%20Mother> accessed on 13 Nov. 2015.

[33] Panda, N. C. (2011). Gods and Goddesses in Indian Art and Literature, Bhartiya Kala Prakashan, Delhi, 394.

[34] Pattanaik, Devdutt (2006a). Myth=Mithya: A Handbook of Hindu Mythology, Penguin Books, 127-128.

[35] Pattanaik, Devdutt (2006b). Myth=Mithya: A Handbook of Hindu Mythology, Penguin Books, 3-4.

[36] Percy, Larry (2003). "Advertising and Brand Equity” Branding and Advertising, Eds. Hansen, Flemming/Christensen, Lars B., Copenhagen Business School Press, Denmark, 13-15.

[37] Rampley, Matthew (2005a). "Visual Culture and Meanings of Culture”, Exploring Visual Culture: Definitions, Concepts, Contexts: Definitions, Concepts, Contexts, Edinburgh University Press, 12-16.

[38] Rampley, Matthew (2005b). "Visual Culture and Meanings of Culture”, Exploring Visual Culture: Definitions, Concepts, Contexts: Definitions, Concepts, Contexts, Edinburgh University Press, 1-3.

[39] Rude, Jarett (2010). "Yantras", Mahavidya. Retrieved <http://www.mahavidya.ca/wpcontent/uploads/2010/08/Rude-Jarett-Yantras.pdf> accessed on 13 Nov. 2015. 
[40] Schultz, Majken, Hatch, Mary J. and Ciccolella, Francesco (2004). How a Brand Lives in Symbols and Artifacts: The Case of LEGO Company, Copenhagen Business School, 8-12.

[41] Schweig, Graham M. (2005). Dance of Divine Love, Princeton University Press, 1-4. Retrieved <http://press.princeton.edu/chapters/i7974.pdf> accessed on 13 Nov. 2015.

[42] Sivapriyananda, Swami (1990). Astrology and Religion in Indian Art, Abhinav Publications, New Delhi, 57-77.

[43] Wilkins, W. J. (2009a). Hindu Mythology, D. K. Printworld (P), Ltd., New Delhi, 78-82.

[44] Wilkins, W. J. (2009b). Hindu Mythology, D. K. Printworld (P), Ltd., New Delhi, 57-58.

[45] Yudkin, Marcia and Stork, Head (2002). "The Benefits of Branding", Named At Last. Retrieved <http://www.namedatlast.com/branding3.htm> accessed on 12 Nov. 2015. 